\title{
Policy Feedback and Government Responsiveness in a Comparative Perspective
}

\author{
Marius R. Busemeyer $\mathbb{D}$
}

Received: 14 September 2021 / Revised: 13 January 2022 / Accepted: 18 January 2022 / Published online: 22 February 2022

(C) The Author(s) 2022

\begin{abstract}
This paper focuses on the transferability of policy feedback and responsiveness theories. These theories have enjoyed a great deal of scholarly interest in the past years and are widely applied in different country contexts. However, this theory transfer tends to be more focused on the empirical challenges while neglecting the fact that it also involves normative implications about representative democracy. These implications, I argue, are strongly influenced by the real-world example of the United States, where the theories were originally developed. More specifically, I contend that bringing in theoretical approaches that are more influenced by European experiences such as neocorporatism and party difference theory affects the depiction of the role of interest groups and party government in policy feedback and responsiveness theories. I conclude by highlighting the contours of an empirical research agenda that might further elaborate on these issues.
\end{abstract}

Keywords USA · Germany · Corporatism · Party difference theory · Political inequality 


\section{Policy Feedback und Responsivität in vergleichender Perspektive}

Zusammenfassung Dieser Artikel beschäftigt sich mit der Übertragbarkeit von Theorien zu Policy Feedback und Responsivität. Diese Theorien haben in den letzten Jahren großes wissenschaftliches Interesse erfahren und finden in unterschiedlichen Länderkontexten ihre Anwendung. Jedoch konzentriert sich dieser Theorietransfer primär auf empirische Herausforderungen und vernachlässigt dabei den Umstand, dass mit diesem Transfer auch normative Implikationen zu repräsentativer Demokratie einhergehen. Diese Implikationen, so argumentiere ich, sind stark geprägt durch den US-amerikanischen Fall, in dessen Kontext diese Theorien ursprünglich entwickelt wurden. Dies gilt insbesondere in Bezug auf die Rolle von Interessengruppen und politischen Parteien, die in eher europäisch geprägten Theorieansätzen wie der Parteiendifferenzthese oder der Theorie des Neo-Korporatismus anders konzeptionalisiert werden als in US-amerikanischen Ansätzen zu Policy Feedback und Responsivität. Der Artikel schließt mit der Konturierung einer Forschungsagenda, welche eine weitere Beschäftigung mit den aufgeworfenen Fragen voranbringen könnte.

Schlüsselwörter USA · Deutschland · Korporatismus · Parteiendifferenztheorie · Politische Ungleichheit

\section{Introduction}

Democracies across the Western world are widely perceived to be in crisis (see, among many others, Levitsky and Ziblatt 2018; Schäfer and Zürn 2021). Questions about selective, biased, or simply nonexistent responsiveness of governments to the concerns of common citizens are often at the core of public and academic crisis diagnoses. If governments primarily respond to the preferences and concerns of political and economic elites (Elsässer et al. 2020; Gilens and Page 2014), thus accepting or even contributing to mounting inequalities in education, work, and life chances, disappointed citizens may increasingly turn to left-wing or right-wing populist parties instead (Burgoon et al. 2019).

Against this background, the motivating idea to start off this particular paper is the observation that while democracy is perceived to be in crisis, it is often done so for different reasons. In the United States, recent years have seen a steep increase in political polarization between the left and the right, an associated rise of partydominated government, and heightened potential for gridlock in Congress when the legislative and executive branches of the government are controlled by different parties. In Germany (and other European countries, even though I focus here mostly on the German case for pragmatic reasons), political polarization has increased as well, associated with the rise of left-wing and right-wing populism. More important for the purpose of this paper, however, is the observation that political polarization "at the fringes" has been accompanied by a convergence of mainstream parties toward the political center, contributing to a blurring of ideological boundaries between these parties. Thus, in short and simplifying greatly, the perceived crisis of demo- 
cratic responsiveness in the United States is partly associated with the rise of party government, while the crisis in Germany (and Europe) is linked to its demise as political parties in the center become ideologically more flexible.

The upshot of this brief example for the purpose of this article is to point to different underlying normative assumptions in the United States and Europe about democracy and representation. The existing literature on policy feedback and government responsiveness, which I will briefly review further below, is typically centered on empirical challenges in transferring policy theories from one context (typically the U.S. case) to others, whereas differences in the underlying normative assumptions about democracy are neglected. This matters, however, because it has direct implications for the crisis diagnosis of democracy and potential remedies to this crisis. Depending on normative conceptions of representation and democracy, the answer may be to strengthen representative party government rather than to weaken it or to boost the involvement of interest groups in decision-making rather than keeping them outside. In this paper, which has an admittedly somewhat speculative flavor, I argue that the strong empirical focus of scholarship on policy feedback and government responsiveness has led to an implicit transfer of normative assumptions about democracy from the U.S. case, for which these theories have originally been developed, to the European context. In a new version of history repeating itself, this paper basically mirrors the approach of classics in comparative politics such as Lehmbruch (1979) and Lijphart (1999) by juxtaposing "European" conceptions of democracy to the liberal-pluralist American model, focusing on the role of political parties and interest groups.

The remainder of this paper is structured as follows: In the next section, I present a brief review of how literature on policy feedback and government responsiveness - which can be regarded as two sides of the same coin-has developed, typically starting with scholarship on the U.S. case and then moving on to other country contexts. In the second half of this paper, I discuss the possibilities and limitations of theory transfer in greater detail. Here, I focus less on the empirical challenges (which have been addressed quite well in the existing literature) and more on the theoretical issues concerning the transfer of implicit normative assumptions about democracy and representation. I focus on interest groups and political parties in turn.

\section{Policy Feedback and Government Responsiveness: A Brief Review}

To some degree, theories of policy feedback and government responsiveness represent two distinct intellectual traditions, with policy feedback theories emerging a bit earlier on the scene (early 1990s) compared with responsiveness theory (mid- to late 1990s). In particular, the historical-institutional tradition in policy feedback theory has paid attention to comparative perspectives early on (e.g., the work by Pierson 
[1994, 1996] and Weaver [2010] on social policy). ${ }^{1}$ Nevertheless, the issues of policy feedback and government responsiveness are deeply intertwined as they relate to the two halves of the feedback loop between the citizenry and policy-makers. As put in explicit terms by Soroka and Wlezien (2010, p. 3), in order for democracy to work properly, "on the one hand, policymakers need to react to the public's policy preferences; on the other hand, the public needs to have informed preferences, based in part on what policymakers are doing." Thus, via policy feedback, policy decisions affect and shape the public's view and evaluation of policy-makers' choices and performance, which in turn, via government responsiveness, affect the electoral fate of political actors as well as their decisions directly. As I will argue in greater detail in the following and below, in both cases-policy feedback and government responsiveness - the initial theories were developed against the background of the U.S. case, and thereby also were shaped by implicit normative assumptions about the relationship between citizens and their elected representatives.

Starting with theories on policy feedback, the first iterations of this theoretical perspective were developed in order to explain the absence of policy change (or, put differently, the dominance of policy stability) in the case of welfare-state policymaking, strongly inspired by the historical institutionalist school of thought (Steinmo et al. 1992). Most famously, Pierson (1993, 1994, 1996, 2000) convincingly argued how existing policies and institutions create concrete benefits for particular welfarestate constituencies, who in turn develop strong material interests in defending these programs against cutbacks (see also Brooks and Manza 2007). Above and beyond material self-interests, existing policies also influence cognitive understandings and normative underpinnings of feasible reform options in policy-making (Pierson 1993, p. 610; Svallfors 2010). Moving from policy preferences to political behavior, other researchers, again using the case of the United States as an empirical example, have shown how the enactment of particular public policies such as Social Security (pensions) or the G.I. Bill (education) triggered processes of political mobilization and participation among the beneficiaries of these programs (Campbell 2002, 2012; Mettler 2005).

The implications of this early wave of scholarship on policy feedback for government responsiveness are ambivalent. On the one hand, policy feedback theory implies that policy-makers shy away from policy decisions that are unpopular with large parts of the electorate, even if these policies would be in line with their ideological predispositions. This implies a high degree of responsiveness of policy-makers to the public's preferences. The classic example for this is Pierson's (1994) analysis of the welfare-state retrenchment agenda of the Reagan and Thatcher governments in the United States and the United Kingdom, respectively. Although these governments had a strong ideological agenda, their actions did not result in major cutbacks of welfare-state policies, according to Pierson, which was due to the self-reinforcing feedback effects of existing policies. On the other hand, as Pierson himself as well as

\footnotetext{
1 This paper focuses less on these historical-institutionalist accounts and more on policy feedback theory in conjunction with studies of public opinion, which tend to be more US-centered. Furthermore, in spite of the comparative angle of historical-institutionalist work on policy feedback, it still retains a somewhat US-centered perspective as I will explain in greater detail below.
} 
others (e.g., Hall and Thelen [2009], Knight [1992], and Moe [2005]) have argued, existing institutional arrangements also have power implications, privileging some individuals over others. To the extent that self-reinforcing policy feedback prevents the balancing out of entrenched power asymmetries, it can also weaken government responsiveness to broader public concerns, for instance when policy reforms are blocked due to the opposition of particularly powerful interest groups.

Following its initial success, the notion of policy feedback has been picked up widely in comparative public policy analysis, in particular in the domain of welfare state research (see Béland and Schlager [2019], Busemeyer et al. [2021], and Larsen [2020] for recent reviews). Notably, much of this work has been more concerned with the impact of policies and institutions on "mass publics" (Pierson 1993, p. 597), i.e., public opinion and welfare-state attitudes, even though Pierson equally emphasized the importance of policy feedback for interest groups. Related to the spread of easily available comparative public-opinion survey data, a central topic in this literature has been the exploration of the association between macro-level welfare-state regimes and micro-level attitudes and preferences (Andreß and Heien 2001; Jaeger 2006, 2009; Larsen 2020; Svallfors 2004). Dubbed critically as the "comparing-attitudesin-regime" industry by Svallfors (2012, p. 8), this literature has struggled to come up with clear-cut findings regarding the link between welfare-state regimes and attitudes. Partly in reaction to this, researchers have started to concentrate more on specific institutional aspects and dimensions of overarching regimes, yielding more robust results (Busemeyer 2013; Fernández and Jaime-Castillo 2013; Gingrich and Ansell 2012; Jordan 2013). Compared with the wealth of studies on policy feedback and attitudes, less comparative work has been done on the feedback effects of policies on voting behavior and electoral choices. An important and influential exception is the edited volume by Kumlin and Stadelmann-Steffen (2014), which comprises a wealth of studies on this issue. More recently, Vlandas and Halikiopoulou (2021) have studied to what extent welfare policies influence the individual likelihood to vote for right-wing radical parties.

The early work on policy feedback was primarily interested in the mechanism of "self-reinforcing feedback," i.e., how and why existing policies and institutions contribute to path dependency and make large-scale policy change more unlikely. In contrast, more recent work has started to pay more attention to the opposite dynamic, i.e., "self-undermining" feedback, which occurs when existing policies may set in motion a dynamic that contributes to increasing support for policy change rather than stability (Jacobs and Weaver 2015; Weaver 2010).

This kind of self-undermining feedback (sometimes misleadingly called "negative" feedback) is an important element of Soroka and Wlezien's (2010) "thermostatic" model of democracy. According to this model, as already briefly mentioned above, citizens react "thermostatically" to changing policies: If policy-makers deliver too much of a particular policy, citizens will react by lowering their support for additional action (in Soroka and Wlezien's framework, this is mostly defined in terms of government spending) in that domain. Policy-makers in turn react to this cooling-off of support by providing less of that particular policy until support increases again (ibid., p. 169). Thus, in short, Soroka and Wlezien find that policymakers largely respond to public opinion and, in particular, to changes in public 
opinion over time. Furthermore, differences between groups (such as low-income vs. high-income citizens) matter less than parallel changes of public opinion over time (ibid., p. 158). This central finding of their book leads them to conclude that "Democracy works. To be exact, representative democracy works" (ibid., p. 182). This positive assessment of the state of representative democracy chimes well with other literature that finds a strong influence of (changing) public opinion on policy change (Burstein 2003; Erikson 2015; Hakhverdian 2010, 2012; Stimson 1991; Stimson et al. 1995). Again, much of the initial work on the "thermostat" model had been done on the U.S. case and other Anglo-Saxon countries (Wlezien 1995, 2004), but Soroka and Wlezien themselves have applied it to other contexts as well, finding support for their argument (Wlezien and Soroka 2012).

In contrast to the generally positive assessment regarding the workings of representative democracy provided by Soroka and Wlezien (2010), a related, but much more critical, literature has identified systematic biases in government responsiveness to the benefit of economic and political elites. In particular, Gilens's (2005, 2012) influential work has shown that public policy choices are more often in line with the preferences of the rich than those of average-income and low-income citizens, again in the case of the United States. Broadening the perspective to include interest groups as well, Gilens and Page (2014) find that policy-making reacts more strongly to preferences from powerful business lobby groups rather than to those of mass-based interest groups, exacerbating inequalities in responsiveness. Although there is not enough space to go into detail here, the work by Gilens has attracted a significant amount of criticism from scholars in the first camp (Branham et al. 2017; Enns 2015; Enns and Wlezien 2011; Stimson 2011), who, among other things, emphasize the point that group-based differences in public opinion may be less pronounced than the extent of parallel changes over time.

Recently, a number of scholars have transferred Gilens's approach to the European context. Most notably, following the research design by Gilens, Elsässer et al. (2017, 2020) have also identified strong biases in the responsiveness of policy-making in Germany in favor of the rich. Related research on other countries has come to similar conclusions (Giger et al. 2012; Peters and Ensink 2015; Rosset et al. 2013; Schakel 2021). In a comprehensive study spanning a large number of OECD countries and, to some extent, bridging the two camps identified above, Schakel et al. (2020) show that government responsiveness can be both "real" and "unequal." More specifically, this study found that public policy does respond to broader patterns in public opinion and that it changes over time, but at the same time, this responsiveness is always biased to some extent to favor the rich (a similar argument had been made by Stimson [2011]).

\section{Possibilities and Limitations of Transfer}

To sum up the main take-away points from the previous section, the literature review has documented a thriving and growing field of research around the notions of policy feedback and government responsiveness. Similar to other theoretical approaches discussed in this special issue, the initial impetus for theory development 
was inspired by the empirical example of the United States. In spite of the fact that both the welfare state and the political system of the United States are quite exceptional, researchers apparently have found the fundamental building blocks of policy feedback and responsiveness theories to be transferable to other country contexts without many problems.

As hinted at above, the supposedly easy transfer of concepts from the United States to other contexts has been facilitated by the fact that most researchers focus on the empirical challenges associated with such a transfer. For instance, Elsässer et al. $(2017,2020)$ have invested a lot of time and effort in replicating the Gilens approach with German data to the best extent possible. Regarding policy feedback theories, the initial dual approach of Pierson $(1993,1994)$ to focus on both public opinion ("mass publics") and interest groups, inspired by more qualitative work in the tradition of historical institutionalism, was somewhat sidelined by quantitative studies that primarily focus on the statistical association between macro-level institutional variables and micro-level attitudes and preferences. The latter-as successful templates for research design - are easier to transfer compared with more comprehensive theoretical accounts of the exact mechanisms by which policies feed back on politics. Incidentally, the historical-institutionalist tradition in policy feedback research that had been more attuned to variation in comparative institutional contexts is typically also more interested in exploring these mechanisms. Again, the empirical focus has therefore facilitated transferability.

Against this background, the purpose of this article is to pay more attention to the limitations of policy theory transfer, thereby discussing the potential implications of such a transfer. I argue that the strong empirical focus of recent work on policy feedback and responsiveness runs the risk of neglecting the implicit normative assumptions about democracy and representation that are entailed in the original versions of these theories, which were largely inspired by the particular case of the United States. In highlighting these limitations, my goal is definitely not to hinder or slow down policy theory transfer, but simply to encourage a more reflective stance toward it. In the following discussion, I draw on empirical examples from the cases of the United States and Germany for pragmatic reasons, while being fully aware that there is, of course, significant variation among political institutions and party systems across European countries. I focus the discussion on two neuralgic points that connect the micro-level of attitudes and preferences and the macro-level of policy-making: interest groups and political parties. I start with the former.

\section{Interest Groups}

As is well known, there is a significant degree of variation in interest mediation systems across countries (Lijphart 1999), i.e., variation in the extent to which interest groups influence policy-making. This empirical variation, in turn, is mirrored in and related to different normative conceptions about the proper role of interest groups in policy-making processes, i.e., to what extent interest groups should influence policymaking. 
The liberal-pluralist view on interest mediation, dominant in the United States and other Anglo-Saxon countries, maintains that a central defining characteristic of a democratic political order is the free competition of organized interests, in which the state should intervene as little as possible in order to prevent the emergence of potential biases (see, representing many, Dahl [1961], for example). Early works on interest groups have already noted, however, that the absence of state intervention may by itself not be sufficient to prevent the emergence of systematic biases in organizational potential. Schattschneider (1960), for instance, points to the inherent advantages of elites in getting organized and mobilized. Olson (1965) in turn highlights the inherent mobilization advantages of "special interests" over diffuse interests, even though the latter may concern more people. Furthermore, in terms of power resources, interest groups in pluralist systems are bound to rely more on what is called "instrumental power" in the literature on business power (Culpepper 2015; Hacker and Pierson 2002), even though the concept also applies to other interest groups. Instrumental power resources simply refer to the amount of economic and fiscal resources that interest groups can marshal in order to finance lobbying activities as a means to influence policy-making. In a liberal-pluralist system, the influence of a particular interest group on policy-making is likely to be strongly related to the amount of instrumental power resources it can accumulate; typically, interest groups representing economically powerful business interests are better placed to do so than citizen-based interest groups (Baumgartner et al. 2009; Gilens and Page 2014).

The neocorporatist view on interest group mediation, which is more common in the European context and Germany, in particular, provides a somewhat different perspective. The theory of neocorporatism emerged in the late 1970s and early 1980s in response to the dominance of liberal-pluralist theories on interest group mediation at that time. The empirical analysis of European democracies (as well as other world regions such as Latin America) had motivated the early proponents of neocorporatism to point out that interest group mediation processes worked quite differently in these cases compared with liberal pluralism and that these differences would not signify deficiencies in the former systems, but rather different normative conceptions about the functional representation of societal interests (Lehmbruch 1979; Schmitter 1979; Streeck and Schmitter 1985). To a significant extent, the different normative views about interest mediation are related to different conceptions about democracy itself, i.e., the by now classic distinction between majoritarian and consensus democracies (Lijphart 1999; Powell 2000). Corporatist interest mediation implies certain restrictions on the free competition between interest groups as priority is given to establishing stable structures of functional representation of different societal stakeholders (employers, farmers, labor unions, etc.). Also, state intervention is accepted to the extent to which it creates a level playing field between different organized interests representing distinct societal groups with differing interests. Another important difference from liberal pluralism is that organized interests are actively involved in governmental decision-making processes via corporatist governance bodies, which allows them to rely more on institutional power resources (via these decision-making bodies) rather than having to resort to open forms of lobbying. 


\subsection{Interest Groups and Policy Feedback}

Now, in the following, I am going to argue that policy feedback and responsiveness theories often rely more or less implicitly on liberal-pluralist conceptions of interest group mediation. Regarding policy feedback theories, earlier work in this tradition was more concerned with interest groups, actually, even though, as mentioned above, Pierson (1993) already theorized the impact of policies on both organized groups and public opinion. More specifically, Pierson (1993, p. 602) argues that policies often provide "the selective incentives that groups are using to overcome collective action problems," suggesting that policies can be a crucial element in facilitating the organization of special interests whose purpose is then to defend the continued existence of these policies. The whole notion of policy feedback, according to Pierson, implies that " $[\mathrm{t}] \mathrm{he}$ activity of interest groups often seems to follow rather than precede the adoption of public policies" (ibid., p. 598). Even though entirely plausible from the perspective of policy feedback theory, this argument implicitly refers to a model of interest mediation in which there is a significant degree of fluctuation as new interest groups emerge while others decline, and all are continuously competing for the scarce resource of access to policy-making. In other words, even the more historical-institutionalist accounts of policy feedback theory that are generally more attuned to cross-country contextual effects implicitly rely on liberal-pluralist models of interest group organization.

This stands in contrast to a neocorporatist perspective in which the major stakeholders in decision-making processes are typically organizations that have existed for decades, if not centuries. In the case of trade unions or employers' associations whose origins date back to the early phase of the Industrial Revolution, it does not make sense to argue that their establishment follows in the wake of the enactment of certain policies, as is suggested by the above quotation from Pierson (1993). Furthermore, at least some of these associations have the character of what Olson (1982) has called "encompassing organizations," representing large parts of society, e.g., broad membership-based unions in the Scandinavian context. As they represent a large part of society, encompassing organizations have an inherent interest in pursuing collective goals rather than maximizing narrowly defined self-interests. Furthermore, the major players in corporatist decision-making bodies are essentially locked into a continued and ever evolving cooperation game with each other, which encourages the build-up of mutual trust and encourages strategies of joint problemsolving rather than bargaining (Scharpf 1997).

For policy feedback, this implies important differences between liberal-pluralist and neocorporatist systems. In classic policy feedback theory, interest groups are depicted as "special" or "vested interests" (see also Moe [2017] for the empirical example of teachers' unions in the United States on this), narrow-mindedly concentrated on defending "their" particular policy program. From this perspective, the growth of the welfare state and the public sector more broadly would be accompanied by the accumulation of special interests attached to their particular programs, promoting gridlock and stifling opportunities for policy change, with potentially deleterious consequences for economic wealth in the long term (Olson 1982). 
From a neocorporatist perspective, policy feedback may work differently. Given that interest groups are more encompassing and long term by nature, they are less attached to particular policy programs. If encompassing organizations take into account broader societal interests, they should be more willing to sacrifice the maximization of short-term, self-interest-related gains in order to facilitate long-term solutions to policy problems. Translated into the language of policy feedback, this means that the "negative" feedback effects of a particular status quo (Weaver 2010) might be sufficient to trigger self-undermining feedback in the sense that interest groups are not single-mindedly bent on defending the status quo but could become important drivers of progressive policy change themselves. In fact, as argued by Jacobs (2011), given the long-term existence of many interest groups, they might be more likely to adopt a long-term perspective in developing their positions than politicians who are bound to electoral cycles. Thus, bringing in the perspective of neocorporatism may lead to a significant shift in the perception of the role of interest groups in policy-making: from narrow-minded "vested interests" to potential allies in promoting collective goals and policy change.

\subsection{Interest Groups and Government Responsiveness}

The distinction between a liberal-pluralist and a neocorporatist perspective on interest groups also matters with regard to government responsiveness. Here, interest groups compete for influence and space on the basically crowded and limited political agenda (Baumgartner et al. 2009). Biases in responsiveness result from the fact that certain interest groups are privileged over others because they can marshal more instrumental power resources - essentially campaign money-which leads to the expectation that business interest groups are more likely to be heard in policymaking than mass-based citizen groups (Gilens and Page 2014). The best remedy against capture of policy domains by special interests remains to promote and uphold competition between a large number of competing interest groups, which leads to a balancing out of conflicting demands, thus increasing the chances that policymakers will actually pay more attention to citizens' demands (Breunig and Koski 2018).

From a neocorporatist perspective, the issue of government responsiveness looks different (Busemeyer 2020). Here, interest groups are regarded not only as amplifying the special interests of particular subgroups but also as encompassing organizations representing important stakeholders in society. The electoral channel of representation is thus complemented by a secondary channel of functional representation, in which citizens are represented not just as voters but also as workers, farmers, teachers, environmental activists, etc. Furthermore, the first parliamentary channel and the second one focusing on functional representation are often de facto intertwined, as it is quite common in neocorporatist countries for high-ranking representatives of employers' associations, trade unions, and other interest groups to be members of parliament (or to move back and forth between parliament and interest group work; see, for instance, Trampusch [2005] for the case of German social policy). 
The involvement of interest groups in governmental decision-making processes thus does not diminish or bias responsiveness, as is implied by the above liberal-pluralist perspective when interest groups callously prevent policy-makers from implementing the true will of the people via lobbying. Rather, the active and deliberate involvement of stakeholder representatives in decision-making processes enhances both responsiveness and representation of policy-making. It expands the "sensing devices" of policy-makers to identify societal demands and also creates a reverse communication channel between governments and citizens by involving interest groups/associations in the implementation of policies, thus creating legitimacy for political decisions. Of course, this is an ideal-typical depiction, and neocorporatism is also prone to the risk of capture by special interests masking as collectively minded organizations. The core argument, however, is that the involvement of interest groups in decision-making processes is not by itself and not inherently a normatively "bad" thing but can-under certain conditions-also improve the responsiveness of policy-making.

Thus, to sum up the discussion of interest groups: The bottom line of the previous discussion is that the original versions of policy feedback and government responsiveness theories, based on the empirical case of the United States, often come along with quite negative views of interest groups as special interests. Transferring the gist of feedback and responsiveness theory to other contexts is feasible and possible, but it should go along with a deeper reflection of the implicit normative implications of these original theories. Most importantly, from a neocorporatist perspective, interest groups - or in the language of neocorporatism, voluntary associations-can play an important role by contributing to joint problem-solving, enhancing the reform capacity of systems by promoting progressive policy change, increasing the legitimacy of decision-making processes, and thereby also increasing the overall responsiveness of policy-making.

\section{Party Politics}

Political parties are essential in liberal democracies in bundling the multiple and partly competitive political demands and preferences of individual citizens into policy programs and election manifestos that allow voters to make informed choices about different policy options (and the governing personnel to implement these policies). Again, simplifying greatly, one can distinguish between a "majoritarian" and a "proportional" perspective on party accountability, representation, and responsiveness (Powell 2000), which broadly maps onto the difference between majoritarian election systems and the associated two-party systems (the United States again being the prime example) and multiparty electoral systems based on proportional representation common in most European countries. I am less concerned with differences between electoral systems as such, however, but rather focus on the differing roles of party government in these contexts.

By "party government" (in German, the term Parteiendemokratie is more common), I mean a form of representative government in which political parties-more than individual legislators or directly elected executive leaders-are the central actors 
in transmitting and translating the diffuse demands of citizen-voters into concrete policy output. In order to give citizens meaningful choices about policy options, party government implies the existence of (more or less) binding election manifestos and party programs/platforms that highlight and identify significant differences between parties competing for office (on party difference theory: Schmidt 1996; on manifesto theory: Budge et al. 2001). Party government also implies a certain closeness between political parties and the state apparatus, which has fueled concerns about capture of state institutions and cartelization promoted by party elites (Katz and Mair 1995; Mair 2013). As I will argue in greater detail below, both the positive and the negative aspects of party government are discernible in debates about the state of democracy in the United States and Europe, although in strikingly different ways. First, however, I comment on the role of political parties in theories of policy feedback.

\subsection{Political Parties and Policy Feedback}

Generally speaking, political parties are strangely absent in theories of policy feedback. As already mentioned, Pierson's (1993) influential contribution on policy feedback theory focuses only on feedback effects on interest groups and public opinion, i.e., individual citizens, not political parties. This is, I posit, clearly related to the more marginal role of political parties (in the sense of party government) in the U.S.-American version of representative democracy. The lack of attention to political parties in policy feedback theory is a pity because parties are likely to play a crucial role as gatekeepers and interpreters of policy changes, thereby framing public opinion.

Looking beyond policy feedback theories in the narrow sense, there is some research literature on party politics and public opinion more broadly that can be connected to policy feedback research. When focusing on the empirical example of the United States, this literature again tends to focus on the negative aspects of party government. For instance, the literature on framing (Druckman et al. 2013; Druckman and Nelson 2003) argues that increasingly polarized partisan elites can and do contribute to the polarization of public opinion. This polarization of public opinion via partisan government is, in the worst case, accompanied by a decline in political knowledge among citizens who are increasingly forming their political attitudes based on partisan ideology and tribal group identities (Achen and Bartels 2017). Furthermore, party political elites deliberately attempt to "craft" public opinion in order to increase public support for decisions that are already made; i.e., instead of implementing the will of the people, they manipulate public opinion after the fact in order to create the illusion of responsiveness (Jacobs and Shapiro 2000, 2002). In the case of the United States, increasingly politicized and polarized media reinforce this trend of partisan polarization (Prior 2013).

Hence, this more pessimistic perspective on the role of party government in policy feedback, strongly influenced by empirical analyses of the U.S. case, implies that the role of political parties in policy feedback is primarily to provide partisan cues to further divide and polarize the electorate, to craft or even manipulate public opinion 
for their own partisan gain, or to simply prevent citizens from forming their own opinions by furthering group and partisanship-based identities based on ideology.

A somewhat different and less pessimistic perspective on the role of parties would regard them as important and legitimate actors, interpreting and translating policy decisions for voters. Of course, many European countries have also witnessed increasing political polarization, associated with the rise of right-wing and partly leftwing populism (Burgoon et al. 2019; Kurer 2020). So, clearly, political parties are no longer able (or willing) to fulfill the function of interpreting and legitimizing policy decisions as before, which might also be a consequence of the fact that political parties in government are increasingly constrained by external factors such as economic globalization and European integration (Tober and Busemeyer 2020; Ward et al. 2011).

But independent of these external constraints, the normative question, which is of greater concern here, is whether political parties are in principle regarded as playing a legitimate, constructive role in transmitting policy decisions to citizens or not. A more sanguine view on party government implies that an important and legitimate function of political parties in interpreting policy decisions is to highlight differences in viewpoints between parties. Making differences visible rather than pretending that differences do not exist would then be regarded as an essential component of a well-functioning form of representative government that ultimately rests and depends on party differences (Schmidt 1996). Group-based or partisanshipbased identities would not merely or only be instruments to promote conflict and polarization, but they would also be recognized as important tools for the social integration of different communities.

\subsection{Political Parties and Responsiveness}

When it comes to the role of political parties in the responsiveness of policy-making to public demands, opinions are equally divided regarding the role of parties, which is, again, related in my view to underlying different normative assumptions about representative democracy. In U.S.-focused accounts, political parties are depicted as potential threats that might prevent policy-makers (as individual legislators) from implementing the true will of the people. Burstein (2003, p. 30), for instance, warns that "political parties may, when in office, enact policies favored by their most ardent supporters rather than the general public." In Soroka and Wlezien's (2010) thermostatic model of representative democracy, the connection between individual citizens and policy-makers should be as direct as possible: "The ongoing interaction between public preferences and policy is [...] fundamental to the functioning of a democratic political system. Indeed, the more the public responds to policy, and policymakers represent public preferences, the more 'efficient' the system, that is, the more effectively-quickly and fully_changes in preferences translate into changes in policy" (ibid., p. 15). The empirical relevance of partisan government is recognized by Soroka and Wlezien, but it is regarded as rather an unnecessary or, in the worst case, illegitimate deviation from the ideal setting above (ibid., p. 40). Consequentially, the overall responsiveness of presidential systems (i.e., the United States) is deemed higher than that of parliamentarian systems because, in the former, 
the presidency itself has an "electoral incentive to represent" (ibid., p. 55) the will of the people, whereas in parliamentarian systems, the government is "shielded" by the parliamentarian majority and can therefore afford to be less representative.

More or less implicitly, these U.S.-centered perspectives on responsive government are built on median voter and related theories (Downs 1957; Meltzer and Richard 1981, but see Cox and McCubbins 2005 for a U.S.-focused theory on "responsible party government" in Congress). Effectively, the essence of "public preferences" is defined by the preferences of the average (median) voter; the ideal of responsiveness is achieved when and if policy-makers deviate as little as possible from this average, and then their responsiveness is immediate and "dynamic" (Stimson et al. 1995), so that changes in preferences are directly translated into changes in policies (Soroka and Wlezien 2010).

A quite different perspective of responsive government and the role of political parties therein is provided in approaches rooted in "partisan" or "party difference" theory (Schmidt 1996; see also Castles 1982; Esping-Andersen 1985; Hibbs 1977; Stephens 1979). Two of the eight "key propositions" of party difference theory highlighted by Schmidt (1996, p. 156) are of particular importance here: "1. Social constituencies of political parties in constitutional democracies have distinctive preferences and successfully feed the process of policy formation with these preferences. 2. Policy orientations of political parties broadly mirror the distinctive preferences of their social constituencies." The remaining key propositions mentioned by Schmidt are mostly concerned with political parties being able to effectively implement their (different) policies when in government. Thus, quite different from median voter theory, the policies of ideal-typical responsive government correspond to the preferences of the electoral or "social" constituencies of the parties in government, and this "partisan" government is able to effectively implement these policies, which amounts to noticeable differences in policy output as the partisan composition of government changes over time. Furthermore, according to the logic of proportional representation, different segments of society are represented in parliament (and often in government) via "their" political parties, which, according to some observers, effectively makes proportional representation systems more responsive to public demands than majoritarian systems (Hobolt and Klemmensen 2005; Huber and Powell 1994).

For sure, the link between political parties and their electoral constituencies has weakened over time as societal cleavages have changed and partisan attachments have loosened. Political competition now is widely recognized to play out in a policy space that is (at least) two-dimensional, which means that political parties have to come up with policy packages that are more directly designed to cater to particular electoral constituencies and supporting groups (Beramendi et al. 2015; Häusermann et al. 2013). To the extent that these constituencies continue to have different policy preferences, party differences at the macro level should still be discernible. Complementary to this "new partisan theory," the "agency-based approach" to partisan theory recently promoted by Wenzelburger and Zohlnhöfer (2020) argues that policy differences between parties are not just a reflection of different constituencies but are likely also related to different positions of party members and elites across parties. 
Both of these approaches - median voter theory and partisan theory-can be read as empirical theories about policy change, but they are also normative theories about representative democracy. These normative connotations are directly related to different perceptions about crises in representative democracy, as briefly mentioned at the beginning of this paper.

In the U.S. context, the crisis diagnosis centers on increasing political polarization, ideological voting in Congress, and "partisan" government. For sure, the overall problem-solving capacity of the U.S. system of government seems to suffer from these developments. This is, however, mostly due to the fact that increased political polarization simply does not fit with an institutional environment, both in Congress itself as well as with regard to the interplay between the three branches of government that is dependent on centrist policy-makers and legislators to prevent gridlock. Regarding "partisan government," academic and public observers adopt a rather critical position of governments that are primarily responsive to social constituencies that were instrumental in the election of presidents, be it rural voters and business elites in the case of the Trump administration (Hacker and Pierson 2020) or urban and highly educated elites as well as ethnic minorities in the cases of the Obama and Biden administrations (King and Smith 2011). The presidency is clearly the institution that is supposed to be particularly focused on representing "all American people" rather than particular subgroups of the population, but these normative implications certainly emanate from the presidency to other elected representatives in the U.S. political system, including, most importantly, individual members of Congress (Miller and Stokes 1963).

In the European (and more specifically in the German) context, the crisis diagnosis is quite different. Starting with Kirchheimer's (1966) diagnosis about the "vanishing opposition" in Germany, increasingly blurred differences between political parties are regarded as rather problematic for representative democracy, as they negatively affect the clarity of the "partisan signal" to the voter. Political polarization-in the form of expanding support for right-wing populism-actually aggravates this problem as traditional left-wing and right-wing "mainstream" parties are effectively forced to enter grand coalitions spanning across the partisan spectrum. The classical definition of a "grand coalition" in the German context is a coalition between the Christian Democratic CDU/CSU and the Social Democratic SPD. But even in constellations where this classical version of a grand coalition is no longer possible or viable, new kinds of grand coalitions involving the liberal Free Democratic Party and the left-wing Greens are emerging, as, for instance, in some eastern German Bundesländer and, following the federal elections of 2021, for the first time on the federal level as well. From the perspective of party difference theory, these types of centrist coalitions could be viewed as problematic because they continue to blur differences between political parties and-most likely-dampen the effect of changes in the partisan composition of government on policy output. From the perspective of median voter theory, however, this could be regarded as an increase in responsiveness as new and old grand coalitions are much more likely to design policies close to the median voter's position compared with traditional "partisan" government coalitions. 


\section{Discussion and Conclusions}

To sum up, the main purpose of this article was to reflect on the possibilities and limitations of transferring policy feedback and responsiveness theories from the largely U.S.-focused context, in which these theories were often originally formulated, to a European context (and potentially beyond). As documented in the brief literature review above, policy feedback and responsiveness theories have already been applied in many comparative studies and are still growing in popularity, but many of these endeavors in theory transfer are mostly focused on the empirical challenges that this transfer entails. The specific contribution of this paper instead is to reflect a bit more critically on the transferability of normative implications about representative democracy — an issue that is less well covered in existing scholarship.

I focused on two issues here: the role of interest groups and the role of political parties. Simplifying somewhat, one could say that the normative references of policy feedback and responsiveness theories-liberal pluralism and median voter theory-hold more negative views on both types of actors compared with more "European-flavored" theories, i.e., neocorporatism and partisan difference theory. This might be related to the fact that American perspectives on representative democracy strongly emphasize the "input" dimension of the democratic process, which prizes a direct_-immediate and dynamic_-connection between voters and their elected representatives. Hence, any type of distraction that might tempt policy-makers to deviate from implementing the will of the people is critically regarded as a "special" interest or partisan constituency.

In contrast, European perspectives - also related to the historical roots of contemporary party and interest mediation systems - have a more positive view of the involvement of interest groups in decision-making processes. The functional representation of different groups via corporatist governance bodies does not necessarily amount to interest group capture of state institutions, but it might enhance the overall responsiveness of policy-making (although conditions apply; see Busemeyer [2020] for a more extensive discussion). Similarly, political parties in government are expected to represent the different interests of particular constituencies, and these competing interests are commonly brought together temporarily in the form of multiparty coalition governments.

In closing, I want to comment on the empirical implications of the above discussion. Rather than simply engaging in theoretical reflection (albeit a worthy exercise by itself), the upshot of this paper's argument is that reflecting more explicitly on the normative implications of the original versions of policy feedback and responsiveness theory can ultimately lead to a new (or at least renewed) empirical research agenda. Regarding policy feedback theory, for instance, one important empirical implication of the discussion above is that policy feedback might work differently for "special interests" and encompassing organizations. As the latter are more concerned with broader public interests, the involvement of encompassing organizations as important societal stakeholders in decision-making processes might not only enhance the overall responsiveness of policy-making but also increase the chances for "self-undermining" policy feedback, i.e., support for policy change if the current status quo produces negative side effects for society at large. 
This kind of research can connect and contribute to emerging work that shows that corporatist systems are better placed to pursue long-term-oriented policies such as the transition toward a decarbonized economy (Finnegan 2020). Another example is the recent dissertation by Bledow (2021) on the role of trade unions in contemporary welfare states. She shows that encompassing trade unions (in her case, Danish trade unions) are more likely to support social investment policies, i.e., policies that are aimed at improving human capital over the long term rather than focusing on shortterm compensatory policies. The latter tend to be more supported by trade unions in countries with a liberal-pluralist interest mediation system (in her case, the United Kingdom).

Regarding responsiveness theory, current scholarship has mainly been concerned with ascertaining whether the pattern of unequal responsiveness identified by Gilens (2012) and others for the case of the United States holds in other countries as well. Some have started to explore whether the responsiveness of governments to public demands depends on the partisan composition of these governments. For instance, Elsässer et al. (2020) do not find left-wing governments to be systematically more responsive to low-income voter preferences than right-wing governments, but in my view, a more encompassing study of the "partisan responsiveness" of governments is still missing. In their conclusion, Elsässer et al. (2020, pp. 14-15) tentatively explain their findings by pointing out a lack of descriptive representation in elected representatives in the sense that members of parliament in general are much more likely to have a university degree compared with the distribution of educational qualifications in the population.

But is it really the case that the fact that both left-wing and right-wing members of parliament hold higher education degrees should dominate any kind of partisanideological differences? Again coming back to the recent contribution by Wenzelburger and Zohlnhöfer (2020) mentioned above, it is likely (and empirically verified) that individuals join political parties in order to promote certain policies and values and that these values are also shared by political elites. Thus, to the extent to which partisan ideologies pay more or less attention to the issue of inequality, partisan responsiveness in government should vary. Or if it really does not vary, it would be worthwhile to study to what extent the lack or bias of responsiveness of governments is really a consequence of the fact that elected representatives from different parties want the same policies, or rather a consequence of external constraints preventing preferred policies from being implemented, such as Europeanization (Tober and Busemeyer 2020). These are obviously important questions that go to the heart of representative democracy and how its different crises might be addressed. The goal of this article has been to motivate other researchers in the field to pick up the baton and contribute to answering them.

Funding Open Access funding enabled and organized by Projekt DEAL.

Open Access This article is licensed under a Creative Commons Attribution 4.0 International License, which permits use, sharing, adaptation, distribution and reproduction in any medium or format, as long as you give appropriate credit to the original author(s) and the source, provide a link to the Creative Commons licence, and indicate if changes were made. The images or other third party material in this article are included in the article's Creative Commons licence, unless indicated otherwise in a credit line to the material. If material is not included in the article's Creative Commons licence and your intended use is not 
permitted by statutory regulation or exceeds the permitted use, you will need to obtain permission directly from the copyright holder. To view a copy of this licence, visit http://creativecommons.org/licenses/by/4. $0 /$.

Conflict of interest M. R. Busemeyer has no conflicts of interest to declare that are relevant to the content of this article.

\section{References}

Achen, Christopher H., and Larry M. Bartels. 2017. Democracy for realists: why elections do not produce responsive government. Princeton: Princeton University Press.

Andreß, Hans-Jürgen, and Thorsten Heien. 2001. Four worlds of welfare state attitudes? A comparison of Germany, Norway, and the United States. European Sociological Review 17(4):337-356.

Baumgartner, Frank R., M. Berry Jeffrey, Marie Hojnacki, et al. 2009. Lobbying and policy change: who wins, who loses, and why. Chicago: University of Chicago Press.

Béland, Daniel, and Edella Schlager. 2019. Varieties of policy feedback research: looking backward, moving forward. Policy Studies Journal 47(2):184-205.

Beramendi, Pablo, Silja Häusermann, Herbert Kitschelt, et al. 2015. Introduction: the politics of advanced capitalism. In The politics of advanced capitalism, ed. Pablo Beramendi, Silja Häusermann, and Herbert Kitschelt, et al., 1-64. Cambridge, New York: Cambridge University Press.

Bledow, Nona R. 2021. Labor unions in the contemporary welfare state: preferences, salience, positions. Doctoral dissertation. Konstanz: University of Konstanz.

Branham, J. Alexander, Stuart Soroka, and Christopher Wlezien. 2017. When do the rich win? Political Research Quarterly 132(1):43-62.

Breunig, Christian, and Chris Koski. 2018. Interest groups and policy volatility. Governance 31(2):279-297. https://doi.org/10.1111/gove.12288.

Brooks, Clem, and Jeff Manza. 2007. Why welfare states persist: the importance of public opinion in democracies. Chicago: University of Chicago.

Budge, Ian, Hans-Dieter Klingemann, Andrea Volkens et al. (eds.). 2001. Mapping policy preferences: estimates for parties, electors, and governments 1945-1998. Oxford, New York: Oxford University Press.

Burgoon, Brian, Sam van Noort, Matthijs Rooduijn, et al, 2019. Positional deprivation and support for radical right and radical left parties. Economic Policy 34(97):49-93.

Burstein, Paul. 2003. The impact of public opinion on public policy: a review and an agenda. Political Research Quarterly 56(1):29-40.

Busemeyer, Marius R. 2013. Education funding and individual preferences for redistribution. European Sociological Review 29(4):707-719.

Busemeyer, Marius R. 2020. Neo-corporatism and the responsiveness of democracy. In The European social model under pressure: liber Amicorum in honour of Klaus Armingeon, ed. Romana Careja, Patrick Emmenegger, and Nathalie Giger, 15-31. Wiesbaden: Springer VS.

Busemeyer, Marius R., Aurélien Abrassart, and Roula Nezi. 2021. Beyond positive and negative: new perspectives on feedback effects in public opinion on the welfare state. British Journal of Political Science 51(1):137-162. https://doi.org/10.1017/S0007123418000534.

Campbell, Andrea. 2002. Self-interest, social security, and the distinctive participation patterns of senior citizens. American Political Science Review 96(3):565-574.

Campbell, Andrea Louise. 2012. Policy makes mass politics. Annual Review of Political Science 15:333-351.

Castles, Francis G. 1982. The impact of parties on public expenditure. In The impact of parties: politics and policies in democratic capitalist states, ed. Francis G. Castles, 21-96. London: SAGE.

Cox, Gary W., and Mathew D. McCubbins. 2005. Setting the agenda: responsible party government in the U.S. House of representatives. Cambridge, New York: Cambridge University Press.

Culpepper, Pepper D. 2015. Structural power and political science in the post-crisis era. Business and Politics 17(3):391-409.

Dahl, Robert A. 1961. Who governs? Democracy and power in an American city. New Haven: Yale University Press.

Downs, Anthony. 1957. An economic theory of democracy. Stanford: Addison Wesley.

Druckman, James N., and R. Nelson Kjersten. 2003. Framing and deliberation: how citizens' conversations limit elite influence. American Journal of Political Science 47(4):729-745. 
Druckman, James N., Erik Peterson, and Rune Slothuus. 2013. How elite partisan polarization affects public opinion formation. American Political Science Review 107(1):57-79.

Elsässer, Lisa, Svenja Hense, and Armin Schäfer. 2017. „Dem Deutschen Volke“? Die ungleiche Responsivität des Bundestags. Zeitschrift für vergleichende Politikwissenschaft 27:161-180.

Elsässer, Lea, Svenja Hense, and Armin Schäfer. 2020. Not just money: unequal responsiveness in egalitarian democracies. Journal of European Public Policy https://doi.org/10.1080/13501763.2020. 1801804.

Enns, Peter K. 2015. Relative policy support and coincidental representation. Perspectives on Politics 13(4):1053-1064.

Enns, Peter K., and Christopher Wlezien. 2011. Group opinion and the study of representation. In Who gets represented?, ed. Peter K. Enns, Christopher Wlezien, 1-25. New York: SAGE.

Erikson, Robert S. 2015. Income inequality and policy responsiveness. Annual Review of Political Science 18:11-29.

Esping-Andersen, Gøsta. 1985. Politics against markets: the social democratic road to power. Princeton: Princeton University Press.

Fernández, Juan J., and Antonio M. Jaime-Castillo. 2013. Positive or negative policy feedbacks? Explaining popular attitudes towards pragmatic pension policy reforms. European Sociological Review 29(4):803-815.

Finnegan, Jared J. 2020. Varieties of de-carbonization? Comparative political economy and climate change. Socio-Economic Review 18(1):264-271.

Giger, Nathalie, Jan Rosset, and Julian Bernauer. 2012. The poor political representation of the poor in a comparative perspective. Representation 48(1):47-61.

Gilens, Martin. 2005. Inequality and democratic responsiveness. Public Opinion Quarterly 69(5):778-796.

Gilens, Martin. 2012. Affluence and influence: economic inequality and political power in America. Princeton: Princeton University Press.

Gilens, Martin, and Benjamin I. Page. 2014. Testing theories of American politics: elites, interest groups, and average citizens. Perspectives on Politics 12(3):564-581.

Gingrich, Jane R., and Ben W. Ansell. 2012. Preferences in context: micro preferences, macro contexts, and the demand for social policy. Comparative Political Studies 45(12):1624-1654.

Hacker, Jacob S., and Paul Pierson. 2002. Business power and social policy: employers and the formation of the American welfare state. Politics \& Society 30:277-326.

Hacker, Jacob S., and Paul Pierson. 2020. Let them eat tweets: how the right rules in an age of extreme inequality. New York: W. W. Norton, Liveright.

Hakhverdian, Armen. 2010. Political representation and its mechanisms: a dynamic left-right approach for the United Kingdom, 1976-2006. British Journal of Political Science 40(4):835-856.

Hakhverdian, Armen. 2012. The causal flow between public opinion and policy: government responsiveness, leadership, or counter movement? West European Politics 35(6):1386-1406.

Hall, Peter A., and Kathleen Thelen. 2009. Institutional change in varieties of capitalism. Socio-Economic Review 7(1):7-34.

Häusermann, Silja, Georg Picot, and Dominik Geering. 2013. Review article: rethinking party politics and the welfare state-recent advances in the literature. British Journal of Political Science 43(1):221-240.

Hibbs, Douglas A. 1977. Political parties and macroeconomic policy. American Political Science Review 71(4):1467-1487.

Hobolt Binzer, Sara, and Robert Klemmensen. 2005. Responsive government? Public opinion and government policy preferences in Britain and Denmark. Political Studies 53:379-402.

Huber, John D., and G. Powell Bingham. 1994. Congruence between citizens and policymakers in two visions of liberal democracy. World Politics 46(3):291-326.

Jacobs, Alan M. 2011. Governing for the long term: democracy and the politics of investment. Cambridge, New York: Cambridge University Press.

Jacobs, Alan M., and R. Kent Weaver. 2015. When policies undo themselves: self-undermining feedback as a source of policy change. Governance 28(4):441-457.

Jacobs, Lawrence R., and Robert Y. Shapiro. 2000. Politicians don't pander: political manipulation and the loss of democratic responsiveness. Chicago, London: University of Chicago Press.

Jacobs, Lawrence R., and Robert Y. Shapiro. 2002. Politics and policymaking in the real world: crafted talk and the loss of democratic responsiveness. In Navigating public opinion: polls, policy, and the future of American democracy, ed. Jeff Manza, Fay Lomax Cook, and Benjamin I. Page, 54-75. Oxford, New York: Oxford University Press. 
Jaeger Meier, Mads. 2006. Welfare regimes and attitudes towards redistribution: the regime hypothesis revisited. European Sociological Review 22:157-170.

Jaeger Meier, Mads. 2009. United but divided: welfare regimes and the level and variance in public support for redistribution. European Sociological Review 25(6):723-737.

Jordan, Jason. 2013. Policy feedback and support for the welfare state. Journal of European Social Policy 23(2):134-148.

Katz, Richard S., and Peter Mair. 1995. Changing models of party organization and party democracy: the emergence of the cartel party. Party Politics 1(1):5-28.

King, Desmond, and Rogers M. Smith. 2011. Still a house divided: race and politics in Obama's administration. Princeton: Princeton University Press.

Kirchheimer, Otto. 1966. Germany: the vanishing opposition. In Political oppositions in western democracies, ed. Robert A. Dahl, 319-345. New Haven: Yale University Press.

Knight, Jack. 1992. Institutions and social conflict. Cambridge: Cambridge University Press.

Kumlin, Staffan, and Isabelle Stadelmann-Steffen. 2014. Citizens, policy feedback, and European welfare states. In How welfare states shape the democratic public: policy feedback, participation, voting, and attitudes, ed. Staffan Kumlin, Isabelle Stadelmann-Steffen, 3-16. Cheltenham Northampton: Edward Elgar.

Kurer, Thomas. 2020. The declining middle: occupational change, social status, and the populist right. Comparative Political Studies 53(10-11):1798-1835. https://doi.org/10.1177/0010414020912283.

Larsen Gahner, Erik. 2020. Policy feedback effects on mass publics: a quantitative review. Policy Studies Journal 47(2):372-394.

Lehmbruch, Gerhard. 1979. Liberal coporatism and party government. In Trends toward corporatist intermediation, ed. Philippe C. Schmitter, Gerhard Lehmbruch, 147-183. Beverly Hils, London: SAGE.

Levitsky, Steven, and Daniel Ziblatt. 2018. How democracies die. New York: Broadway Books.

Lijphart, Arend. 1999. Patterns of democracy. New Haven: Yale University Press.

Mair, Peter. 2013. Smaghi versus the parties: representative government and institutional constraints. In Politics in the age of austerity, ed. Armin Schäfer, Wolfgang Streeck, 143-168. Cambridge: Polity.

Meltzer, Allan H., and Scott F. Richard. 1981. A rational theory of the size of government. Journal of Political Economy 89(5):914-927.

Mettler, Suzanne. 2005. Soldiers to citizens: the G.I. Bill and the making of the greatest generation. Oxford, New York: Oxford University Press.

Miller, Warren E., and Donald E. Stokes. 1963. Constituency influence in congress. American Political Science Review 57(1):45-56.

Moe, Terry M. 2005. Power and political institutions. Perspectives on Politics 3(2):215-233.

Moe, Terry M. 2017. Teachers unions in the United States: the politics of blocking. In The comparative politics of education: teacher unions and education systems around the world, ed. Terry M. Moe, Susanne Wiborg, 24-55. Cambridge, New York: Cambridge University Press.

Olson, Mancur. 1965. The logic of collective action: public goods and the theory of groups. Cambridge: Harvard University Press.

Olson, Mancur. 1982. The rise and decline of nations: economic growth, stagflation, and social rigidities. New Haven: Yale University Press.

Peters, Yvette, and Sander J. Ensink. 2015. Differential responsiveness in Europe: the effects of preference difference and electoral participation. West European Politics 38(3):577-600.

Pierson, Paul. 1993. When effect becomes cause: policy feedback and political change. World Politics 45(4):595-628.

Pierson, Paul. 1994. Dismantling the welfare state? Reagan, thatcher, and the politics of retrenchment. Cambridge: Cambridge University Press.

Pierson, Paul. 1996. The new politics of the welfare state. World Politics 48:143-179.

Pierson, Paul. 2000. Increasing returns, path dependence, and the study of politics. American Political Science Review 94(2):251-267.

Powell, Bingham G. 2000. Elections as instruments of democracy: Majoritarian and proportional visions. New Haven, London: Yale University Press.

Prior, Markus. 2013. Media and political polarization. Annual Review of Political Science 16:101-127. https://doi.org/10.1146/annurev-polisci-100711-135242.

Rosset, Jan, Nathalie Giger, and Julian Bernauer. 2013. More money, fewer problems? Cross-level effects of economic deprivation on political representation. West European Politics 36(4):817-835.

Schäfer, Armin, and Michael Zürn. 2021. Die demokratische Regression. Frankfurt a.M.: Suhrkamp.

Schakel, Wouter. 2021. Unequal policy responsiveness in the Netherlands. Socio-Economic Review 19(1):37-57. https://doi.org/10.1093/ser/mwz018. 
Schakel, Wouter, Brian Burgoon, and Armen Hakhverdian. 2020. Real but unequal representation in welfare state reform. Politics \& Society 48(1):131-163.

Scharpf, Fritz W. 1997. Games real actors play: actor-centered institutionalism in policy research. Boulder: Weastview.

Schattschneider, Elmar Eric. 1960. The semisovereign people: a realist's view of democracy in America. Chicago: Holt, Rinehart and Winston.

Schmidt, Manfred G. 1996. When parties matter: a review of the possibilities and limits of partisan influence on public policy. European Journal of Political Research 30(2):155-183.

Schmitter, Philippe C. 1979. Still the century of corporatism? In Trends toward corporatist intermediation, ed. Philippe C. Schmitter, Gerhard Lehmbruch, 7-52. Beverly Hills, London: SAGE.

Soroka, Stuart N., and Christopher Wlezien. 2010. Degrees of democracy: politics, public opinion, and policy. Cambridge, New York: Cambridge University Press.

Steinmo, Sven, Kathleen Thelen, and Frank Longstreth (eds.). 1992. Structuring politics: historical institutionalism in comparative analysis. Cambridge: Cambridge University Press.

Stephens, John D. 1979. The transition from capitalism to socialism. London: Macmillan.

Stimson, James A. 1991. Public opinion in america: moods, cycles, and swings. : Westview Press.

Stimson, James A. 2011. The issues in representation. In Who gets represented?, ed. Peter K. Enns, Christopher Wlezien, 347-360. New York: SAGE.

Stimson, James A., Michael B. MacKuen, and Robert S. Erikson. 1995. Dynamic representation. American Political Science Review 89(3):543-565.

Streeck, Wolfgang, and Philippe C. Schmitter. 1985. Community, market, state—and associations? The prospective contribution of interest governance to social order. In Private interest government: beyond market and state, ed. Wolfgang Streeck, Philippe C. Schmitter, 1-29. London, Beverly Hills, New Delhi: SAGE.

Svallfors, Stefan. 2004. Class, attitudes and the welfare state: Sweden in comparative perspective. Social Policy \& Administration 38(2):119-138.

Svallfors, Stefan. 2010. Policy feedback, generational replacement, and attitudes to state intervention: eastern and western Germany, 1990-2006. European Political Science Review</i> 2(1):119-135.

Svallfors, Stefan. 2012. Welfare states and welfare attitudes. In Contested welfare states: welfare attitudes in Europe and beyond, ed. Stefan Svallfors, 1-24. Stanford: Stanford University Press.

Tober, Tobias, and Marius R. Busemeyer. 2020. Breaking the link? How European integration shapes social policy demand and supply. Journal of European Public Policy https://doi.org/10.1080/13501763. 2020.1824010 .

Trampusch, Christine. 2005. From interest groups to parties: the change in career patterns of the legislative elite in German social policy. German Politics 14(1):14-32.

Vlandas, Tim, and Daphne Halikiopoulou. 2021. Welfare state policies and far right party support: moderating 'insecuriy effects' among different social groups. West European Politics https://doi.org/10. 1080/01402382.2021.1886498.

Ward, Hugh, Lawrence Ezrow, and Han Dorussen. 2011. Globalization, party positions, and the median voter. World Politics 63(03):509-547. https://doi.org/10.1017/S004388711100013X.

Weaver, R. Kent. 2010. Paths and forks or chutes and ladders?: negative feedbacks and policy regime change. Journal of Public Policy 30(2):137-162.

Wenzelburger, Georg, and Reimut Zohlnhöfer. 2020. Bringing agency back into the study of partisan politics: a note on recent developments in the literature on party politics. Party Politics https://doi.org/10. $1177 / 1354068820919316$.

Wlezien, Christopher. 1995. The public as thermostat: dynamics of preferences for spending. American Journal of Political Science 39(4):981-1000.

Wlezien, Christopher. 2004. Patterns of representation: dynamics of public preferences and policy. Journal of Politics 66(1):1-24.

Wlezien, Christopher, and Stuart N. Soroka. 2012. Political Institutions and the Opinion-Policy Link. West European Politics 35(6):1407-1432. 